\title{
The Effects of Fiscal Policy on Ghanaian Economy
}

\author{
Andrews D. Agblobi* Charity Aborjoe \\ Dave Dadzie Tandoh Renghis Ahiable Jeremiah Nii-Odai Mensah \\ Department of Banking \& Finance, University of Professional Studies, Accra \\ P.O Box LG 149
}

\begin{abstract}
As part of the Government role in formulating and implementing policies that drives economic output, the need to examine whether or not these policies affect economic growth is useful and timely. The study was conducted by regressing economic output on four fiscal variables such as: government consumption expenditure, taxes, and government investment expenditure and government transfers whilst private investments, labour force and terms of trade as the non-fiscal variables. The analyses were based on time series data covering the period of 1980-2016. The study applies the Dickey-Fuller test for stationary and bounds test approach to cointegration for the estimation of an autoregressive distributed lag model. The result shows that in the long-run government investments and government expenditure affect economic growth positively.
\end{abstract}

Keywords: Expenditure, Growth, Fiscal policy; Budget; Government spending; GDP

DOI: $10.7176 / \mathrm{EJBM} / 11-26-14$

Publication date:September $30^{\text {th }} 2019$

\section{INTRODUCTION}

Traditionally, the Keynesian macroeconomics debate on economic growth focuses on influence such as monetary policy, economic structure and fiscal policy variables on the economic outcome (Olasunkani and Badatunde, 2012). The economic growth which is the percentage change of the gross domestic product (GDP) from one period to the other could be a results of a number of factors. To the Keynesian, above policies championed by the Government could affect the economic output either positively or negatively (Onyeiwa, 2012). The choice of which factor to concentrate in a study may depend on the objective and availability of data.

The debate on fiscal policy in economic growth received new prominence in the aftermath of the 2008/9 global financial crisis (Ocran, 2011). In 2018 and 2019, there is renewed call for fiscal stimulus following a perception that monetary policy has run it full course with low interest rates around the world. Fiscal policy that describes how Government uses its taxes, spending and borrowing to influence economic output continue to be identified as one of the main variables that affect economic performance of a country.

In early 2018, the United States of America Government embarked on large tax cuts (i.e. by lowering corporate tax from $35 \%$ to $21 \%$ ) to boost its economic growth. The outcome as at the end of the year 2018 received mixed reactions as the issue of the "trade-war" between the two biggest economies escalates on 'tit-for-tat' imposition of taxes on each other's imports. Nevertheless, economic outturn of United States of America was around 3 percent with a strong macroeconomic fundamental as at the start of the first quarter of 2019. The dominancy of Government activities in most developed economies have facilitated macroeconomics debate about the role of Government in economic prosperity of a nation (Adefeso and Salawu, 2010; Auten and Gee, 2009).

The classical economic debate on economic growth rather emphasis on productivity driven by firms and households, thus private sector participation in economic activities. In August 2018, Apple, an Andriod Phone and other service firm in United States of America became the first firm to reach the 1trillion US Dollar value in the world. The economic success of such a firm is supported by the proponents of the free-market ideology. The classical economists share the view that the less involvement of Government activities in direct productive sectors of the economy, the better the economy outcome. However, the Keynesian economists do share the view that the more the dominance of Government, the better. The ingenuity of the private sector to spot an opportunity and deplore all efforts to pursue which eventually drive economic growth is of essence in the classical economic debate. Therefore, the expectation that Government should create the enabling environment and allow the private sector to drive the economic growth cannot be overlooked in the neoclassical debate. The ability of firms to employ factors of production as inputs to generate an output would drive economic growth.

In early 2017, the new Government of Ghana abolished and decreased a number of taxes with the aim to revamp the economy and assist the private sector to strive. It abolished and reduced a number of taxes termed as 'nuisances' in its first budget to the nation. It achieved an economic growth of 7.4\% in 2017 from $3.5 \%$ in 2016 but missed its revenue target. In such an outcome, would fiscal policy be able to deliver the intended purpose of economic growth in a sustainable period for the country?

Although such a policy can have a positive effect on economy growth at least in the short run, the rising expenditure of the government and the cascading effects of less revenue generation coupled with the rising debt levels create concerns (Prasad, 2009). Taxation is possibly the only rational means of Government to raise revenue 
to finance its spending on goods, services and capital projects (Rosen, 2004). Therefore, if Government should reduce those sources at the detriment of revenue, then, there are concerns.

Government can borrow to finance its budget deficits when the need arises. However, when the government borrow, it competes with the private sector for the limited funds to execute investment projects. This type of situations affects private investment negatively. The Government of Ghana has in the past attempted different methods to boost economic growth. For instance, the instruments used were cost recovery measures, reduction of subsidies, divestiture of State-owned enterprises, retrenchment of civil servants, improvements in the efficiency of tax collection, widening of the tax net and general fiscal policy (Rena and Kefela, 2011; Aryeetey, Harrigan, and Nissanke, 2000). These policies were meant to reform the public sector and enhanced Government revenue mobilization to become self-reliance. However, it was difficult to achieve such aim as different Governments come and goes leaving debts behind to be finance by their successive ones. The debt overhang problem has taken the country in and out of International Monetary Fund (IMF) programmes several times.

The objective of this study is to investigate the effect of fiscal policy on economic growth in Ghana. More specifically, to investigate the issue of whether fiscal policy variables have been relevant in promoting economic growth in Ghana in the long run. The fiscal policy variables investigated include: Taxes (TX), Government Consumption expenditure $(G C)$, Government Investment $(G I)$ and General Government Transfers $(G T)$. The nonfiscal variables are: Labour force $(L)$, Private Investments $(P I)$ and Terms of Trade $(T O T)$.

The essence of the study is rooted in the understanding that government expenditure and tax policies affects economic growth for most developing countries and Ghana is no exception (Yusuff, 2011). Notwithstanding, the concern that fiscal policy may be less successful, in the case of Ghana, some literature supports fiscal policy as a vital tool in the promotion of economic growth (Oshewolo, 2010). A few studies include Dosi, Fagiolo, and Roventini (2010); Gupta and Mulas-Granados (2005) share the view of that Keynesian and endogenous theories have used fiscal policy promote to economic growth. In examining the growth of the economy, a change in the real GDP was used as the measure of economic growth. The rest of the study is organized as Section 2 discusses the methods employed and the data source. Section 3 summaries empirical results and Section 4 concludes and discusses the policy implications.

\section{METHODOLOGY}

\section{Model specification, estimation method and data collection}

An endogenous growth model using production function specified in similar work by Ocran (2011) was adopted in this analysis. The economic output which is the real GDP was used as dependent variable. The independent variables were fiscal policy variables such as Taxes $(T X)$, Government Consumption expenditure $(G C)$, Government Investment $(G I)$ and General Government Transfers $(G T)$ and non-fiscal policy variables such as Labour force $(L)$, Private Investments $(P I)$ and Terms of Trade (TOT). It considers fiscal policy to be the changes in government spending and taxes, and assume that aggregate output is determined by a set of fiscal variables and non-fiscal variables. Thus, the aggregate output expressed in a functional form as:

$$
Y_{t}=f X_{t}, Z_{t}
$$

where $Y$ represents the aggregate output in the economy (i.e. real GDP), $t$ denotes time period, $X$ comprises a set of fiscal variables and $Z$ comprises a set of non-fiscal variables. From equation (1) the operational model for estimation was specified in log-linear form as:

$$
\begin{aligned}
\log Y_{t}= & \alpha_{0}+\alpha_{1} \log G C_{t}+\alpha_{2} \log G T_{t}+\alpha_{3} \log G I_{t}+\alpha_{4} \log T X_{t}+\alpha_{5} \log L_{t}+ \\
& \alpha_{6} \log T O T_{t}+\alpha_{7} \log P I_{t}+\varepsilon_{t}
\end{aligned}
$$

where $\alpha_{0}$ is the constant , $\alpha_{1}, \alpha_{2}, \alpha_{3}, \alpha_{4}, \alpha_{5}, \alpha_{6}, \alpha_{7}$ are the coefficients and $\varepsilon_{t}$ is the error term at $5 \%$ confidence level, indicating all other variables affecting growth but was omitted from the model. $G C_{t}, G T_{t}, G I_{t}$, $T X_{t}, L_{t}, T O T_{t}, P I_{t}$ represents Government consumption, Government transfers, Government investment, Taxes, Labour force, Term of trade and Private investment at time $t$ respectively. The relevance of using the logarithm form of the equation is that each of the parameters estimated indicates the respective variable's elasticity and thus, equation (2) represents how much a percentage change in one of the explanatory variables affect output. Gujarati (2004) argues that the log-linear transformation very often reduces the problem of heteroscedasticity.

\section{Data sources}

The study used annual time series data obtained from the official sources in Ghana covering the period of 19802016. The data sets for real GDP, Government Consumption Expenditure, Terms of Trade, Private Investments and Labour force, as well as Government Transfer Payments, Government Investment Expenditure, and Taxes were obtained from the Ministries of Finance and Economic Planning and the Ghana Statistical Service. Government Revenue and Spending data were collected from the Bank of Ghana and Ministry of Finance and Economic Planning. The real GDP was measured in constant currency terms in the Ghana Cedis denominations 
as published by the Bank of Ghana. All the fiscal variables were expressed in constant prices. Gross Private Investment at constant prices was used to account for the amount of Private Investments in the economy. Terms of Trade was measured as the ratio of Ghana's average export price to its average import price and Labuor was measured by the size of the total labour force in Ghana (Topalova \& Khandelwal, 2011).

\section{Estimation method}

In investigating the effect of the fiscal policy on the economy, four fiscal variables together with three non-fiscal variables were used in running the regression in an Autoregressive Distributed Lag (ARDL) model. The use of an ARDL model was to consider the short-run and long run dynamics. The ARDL approach to cointegration was employed to estimate the effect of the fiscal and non-fiscal variables on the economy for the period 1980-2016.

\section{Unit root testing}

A unit root test was undertaken to avoid spurious regression using secondary source of data. The variables specified in the equation (2) were each tested to ascertain whether they are stationary or not. The study used Dickey-Fuller test with Generalized Least Squares Detrending (DF-GLS) for the evaluation. The null and the alternate hypothesis for the presence of unit root in the variable which is the detrened series for the Dickey-Fuller test with Generalized Least Squares tests are:

Ho: $\delta=0$

$H 1: \delta<0$

If the null hypothesis: $H o: \delta=0$ (the variable under consideration is a unit root) is not rejected, then it indicates that the variable is non-stationary, if the alternate hypothesis: $H 1: \delta<0$ is found to be true, then the variable under consideration is stationary.

\section{Cointegration}

Cointegration was undertaken to investigate the existence of a long-run equilibrium between two or more timeseries variables which are individually non-stationary at their level form (Gujarati, 2004). In order to access the effect of the fiscal variables on the economy of Ghana, the study specified real GDP as a function of a set of fiscal variables and non-fiscal variables including lags of GDP and lags of the explanatory variables in the form of ARDL. The adoption of an ARDL model rather than a static one was meant to capture all the dynamic responses in the dependent and explanatory variables. A static equation may fail to capture immediate, short-run and long-run effects in the model.

\section{RESULTS AND DISCUSSIONS}

From the Dickey-Fuller unit roots test results in Table 1, three fiscal variables were stationary and one nonstationary at 5\% significant level. This means that government expenditure have significant impact on economic changes over time with taxes, government transfer payments and government consumption expenditure remaining constant over time. The results also show that labour force is stationary, hence, constant overtime.

\section{TABLE 1 Unit root test}

\begin{tabular}{lcc}
\hline Variables & P-value & Conclusion \\
\hline GDP & 0.7456 & Not stationary \\
Private Investment & 0.0518 & Not stationary \\
Labour & 0.0083 & Stationary \\
Terms of Trade & 0.1363 & Not stationary \\
Tax & 0.0336 & Stationary \\
Government Investment & 0.4236 & Not stationary \\
Government Transfers & 0.007 & Stationary \\
Government Consumption & 0.00112 & Stationary \\
\hline
\end{tabular}

Source: Author's estimates, June 2018.

\section{Results of ordinary least square}

The results from the OLS at 5\% level of significant in Table 2 shows that Government Investment is significant and promotes economic growth in Ghana. The result shows that fiscal policy variables significantly contribute to economic growth at least in the short-run. The results further show that all the fiscal variables positively affect economic growth with the exception of term of trade is non-fiscal variable which have a negative impact on economy. 
Table 2 Results of Ordinary Least Square Model

\begin{tabular}{lllll}
\hline & Coefficient & Std. Error & t-ratio & p-value \\
\hline Const & $6.09693 * *$ & 2.86206 & 2.1303 & 0.0418 \\
Private Inv. & $0.0796931^{* *}$ & 0.0382324 & 2.0844 & 0.0460 \\
Labour & $0.148672^{* *}$ & 0.0591343 & 2.5141 & 0.0177 \\
Terms of T. & -0.154836 & 0.279202 & -0.5546 & 0.5834 \\
Tax & $0.108623^{* *}$ & 0.0487947 & 2.2261 & 0.0339 \\
Gov. Invest & $0.140074^{* * *}$ & 0.0317818 & 4.4074 & 0.0001 \\
Gov. Trans & $0.131744^{* * *}$ & 0.0393244 & 3.3502 & 0.0023 \\
Gov. Cons. & $0.162364 * * *$ & 0.0549996 & 2.9521 & 0.0062 \\
\hline
\end{tabular}

Source: Author's Estimation, 2018

Government spending, as expected, had a positive effect on the economy both in the short-run and the long run. This kind of government spending may have affected economic output directly or indirectly through its complementary role to private investments. This implies that the Ghanaian economy is likely to experience considerable growth rates in the future, if more resources are directed towards government investment spending.

The results also indicates that government transfers payments such as social intervention programmes have a significant positive impact on economic output. This prevails both in the short run and the long run. This outcome supports the Keynesian theory that Government transfer payments are necessary not only for improving income distribution but also to promote economic growth.

Regarding the non-fiscal variables, the signs obtained from the long-run estimation supports the theoretical predictions. The size of labour as well as private investments in the economy exhibits a significant positive effect on economic growth in the long-run. Associated with the rise in private investments and labour force in Ghana is large enough to produce the needed goods and services. The results showed a positive relationship between growth and the size of the labour force in the economy. Similarly, the impact of private investments remained positively related to economic growth.

\section{Cointegration results}

In the Table 3, the results show that the p-values for the cointegration estimates for Government investment and Government consumption are significant. Thus, the null hypothesis of no long-run cointegration between the variables can be rejected.

The results show that the p-value for Government investment on Government transfer, Government consumption, GDP, Private investment, Labour, Terms of trade, taxes and Government consumption on GDP, Private investment, Labour, Terms of trade, taxes and Government transfer are significant at $5 \%$ percent level while Government transfer on Government consumption, GDP, Private investment, Labour, Terms of trade, taxes and Government investment was significant at $10 \%$ level. The results of the bounds test for cointegration proved that the fiscal variables affect Ghana's economic growth in the long-run. It shows that the fiscal policy does not only affect economic growth in the short run but also at the long-run.

Table 3 Results of Cointegration Test

\begin{tabular}{lcc}
\hline Dependent variable & p-values & Conclusion \\
\hline $\mathrm{F}_{\mathrm{GDP}}(\mathbf{G D P} / \mathrm{PI}, \mathrm{L}, \mathrm{TOT}, \mathrm{TX}, \mathrm{GI}, \mathrm{GT}, \mathrm{GC})$ & 0.9983 & No cointegration \\
$\mathrm{F}_{\mathrm{PI}}(\mathbf{P I} / \mathrm{L}, \mathrm{TOT}, \mathrm{TX}, \mathrm{GI}, \mathrm{GT}, \mathrm{GC}, \mathrm{GDP})$ & 0.1111 & No cointegration \\
$\mathrm{F}_{\mathrm{L}}(\mathbf{L} / \mathrm{TOT}, \mathrm{TX}, \mathrm{GI}, \mathrm{GT}, \mathrm{GC}, \mathrm{GDP}, \mathrm{PI})$ & 7.505 & No cointegration \\
$\mathrm{F}_{\mathrm{TOT}}(\mathbf{T O T} / \mathrm{TX}, \mathrm{GI}, \mathrm{GT}, \mathrm{GC}, \mathrm{GDP}, \mathrm{PI}, \mathrm{L})$ & 0.1368 & No cointegration \\
$\mathrm{F}_{\mathrm{TX}}(\mathbf{T X} / \mathrm{GI}, \mathrm{GT}, \mathrm{GC}, \mathrm{GDP}, \mathrm{PI}, \mathrm{L}, \mathrm{TOT})$ & 0.1416 & No cointegration \\
$\mathrm{F}_{\mathrm{GI}}(\mathbf{G I} / \mathrm{GT}, \mathrm{GC}, \mathrm{GDP}, \mathrm{PI}, \mathrm{L}, \mathrm{TOT}, \mathrm{TX})$ & 0.0017 & Cointegration \\
$\mathrm{F}_{\mathrm{GT}}(\mathbf{G T} / \mathrm{GC}, \mathrm{GDP}, \mathrm{PI}, \mathrm{L}, \mathrm{TOT}, \mathrm{TX}, \mathrm{GI})$ & 0.0843 & No cointegration \\
$\mathrm{F}_{\mathrm{GC}}(\mathbf{G C} / \mathrm{GDP}, \mathrm{PI}, \mathrm{L}, \mathrm{TOT}, \mathrm{TX}, \mathrm{GI}, \mathrm{GT})$ & 0.0084 & Cointegration \\
\hline
\end{tabular}

Source: Author's Estimation, June 2018

\section{CONCLUSION}

The overall analyses and the results obtained in this study do attest that government spending and taxes have significant impact on the Ghanaian economy. The study suggests that the level of government spending and taxes in an economy can be effective in promoting economic growth in the country and may be emulated by other developing countries. It is also evident that the set of non-fiscal variables in the study have also had significant impact on economic growth.

With the findings in this study, the following policy implication can be considered: First, the Government needs to increase its capital investment expenditures and introduce policies that protects and enhance private investments. Government should endeavor to control the policies that may compete with the private sector for the 
limited investible funds. Second, the governments may increase its social transfer payment while ensuring that funds are properly directed towards areas that drive economic growth.

\section{REFERENCES}

Adefeso H. A., H. M., \& Salawu B. (2010). Fiscal Policy and Economic Growth in Nigeria. Journal of economic Theory, 37-43.

Aryeetey E., Harrigan. J., \& Nissanke M. (2000). Economic Reforms in Ghana. Accra, Oxtord: Woeli Publishing service.

Auten, G., \& Gee, G. (2009). Income Mobility in the United States: New Evidence from Income Tax Data . National Tax Journal, 301-328.

Dosi, Giovanni; Fagiolo, Giorgio; and Roventini, Andrea (2010). Schumpeter meeting Keynes: A policy- friendly model of endogenous growth and business cycles. Journal of Economic Dynamics and Control. Elsevier. Vol. 34 (9). 1748-1767.

Gupta, S. C., \& Mula-Grandos, C. (2002). Expenditure Composition, Fiscal Adjustment and Growth in LowIncome Countries. 2-7.

Ocran, M. K. (2011, March 9). Fiscal Policy and Economic Growth in South Africa. Economic Development in Africa, pp. 22-24.

Olasunkani, O. I., \& Badatunde, O. A. (2012). Fiscal Policy Variables-Growth Effect. American Journal of Business and Management, vol. 1, no. 5, 100-107.

Onyeiwa, Charles (2012). Monetary Policy and Economic Growth of Nigeria. Journal of Economic and Sustainable Development. Vol.3, No. 7. 62-70.

Oshewolo, Segun (2010). Galloping poverty in Nigeria: an appraisal of government interventionist policies. Journal of Sustainable Development in Africa, 12(6), 264-274.

Prasad, E. S. (2009). Is the Chinese growth miracle built to last? China Economic Review, 20(1), 103-123.

Rena, R., \& Kefela, G. T. (2011). Restructuring a Fiscal Policy Encourages Economic Growth-A Case of Selected African Countries. Journal of Economics and Business, Vol. 14(2), 23-39.

Rosen, H. S. (2004). Public finance. In The encyclopedia of public choice, Springer Link: HYPERLINK "https://link.springer.com/chapter/10.1007/978-0-306-47828-4_21" https://link.springer.com/chapter/10.1007/978-0-306-47828-4_ 21 (pp. 252-262).

Saad, W., \& Kalakeck, K. (2009). The Nature of Government Expenditure and its Impact on Sustainable Economic Growth. Euro Journal Publishing Inc.

Topalova, Petia and Khandelwal, Amit (2011). Trade Liberation and Firm Productivity: The Case of India. Review of Economics and Statistics. The MIT Press. Vol.93 (3). 995-1009.

Yusuff, Olabisi Scherifat (2011). A Theoretical Analysis of Concept of Informal Economy and Informality of Developing Countries. European Journal of Social Sciences. Vol,20(4). 624-636. 